\title{
Vocal Pedagogy and the Alexander Technique: a reflection
}

\section{La pedagogía vocal y la Técnica Alexander: una reflexión}

\author{
Louise Phelan ${ }^{1,2,3}$ (1) 잉 \\ ${ }^{1}$ Instituto Nacional de Bellas Artes y Literatura; Ciudad de México; México. \\ ${ }^{2}$ Orquesta Escuela Carlos Chávez; Sistema Nacional de Fomento Musical; Ciudad de México; México. \\ ${ }^{3}$ Ensamble Escénico Vocal; Sistema Nacional de Fomento Musical; Ciudad de México; México.
}

\author{
Correspondence \\ Louise Phelan. \\ Email: louisemariephelan@gmail.com

\section{How to cite} \\ Phelan, Louise. (2021). Vocal Pedagogy \\ and the Alexander Technique: a reflection. \\ Revista de Investigación e Innovación en \\ Ciencias de la Salud. 3(2), 128-135. \\ https://doi.org/10.46634/riics.83
}

\section{Received: 15/09/2021 \\ Revised: 11/10/2021 \\ Accepted: 05/11/2021}

\section{Invited editor}

Carlos Manzano Aquiahuatl, MD, MSc.

\section{Editor en jefe}

Jorge Mauricio Cuartas Arias, Ph.D.

\section{Coeditor}

Fraidy-Alonso Alzate-Pamplona, MSc.

Copyright $\subset$ 2021. Fundación Universitaria María Cano. The Revista de Investigación e

Innovación en Ciencias de la Salud provides open access to all its content under the terms of the Creative Commons AttributionNonCommercial-NoDerivatives 4.0

International (CG BY-NG-ND 4.0).

\section{Conflicts of Interest}

The author has declared that no competing interests exist.

\section{Data Availability Statement}

All relevant data is in the article and in the appendices. For more detailed information, write to the Corresponding Author.

\begin{abstract}
This article is a reflection about the role of the Alexander Technique and its application and influence in vocal pedagogy. It is based on more than seventeen years of active teaching as a qualified Alexander Technique Teacher and as a professional singer, working alongside vocal pedagogues, teachers, students and professionals. Its objective is to reflect upon the role of body awareness, psychophysical and emotional consciousness, and wellbeing in the realms of vocal pedagogy and singing.
\end{abstract}

\section{Key words}

Awareness; body-mind; psychophysical; Alexander Technique; pedagogy; wellbeing; integration; connection; freedom; voice; vocology.

\section{Resumen}

El presente artículo corresponde a una reflexión sobre la Técnica Alexander, su aplicación e influencia dentro del ámbito de la pedagogía vocal. Está basado en los últimos diecisiete años de carrera activa como profesora de Técnica Alexander y cantante profesional, trabajando con cantantes y profesores de canto con el objetivo de lograr una buena reflexión de la importancia del proceso de consciencia corporal, conexión sicofísica y bienestar en la pedagogía vocal.

\section{Palabras clave}

Consciencia; sicofísica; Técnica Alexander; pedagogía; bienestar; integración; conexión; libertad; voz; vocología.

\section{Introduction}

Alexander Technique, what is it? Can a more consciously informed body better inform the voice? What is a vocal pedagogue's role when it comes to a singer's mind-body experience and connection? As teachers, is what we conceive as good singing posture really "good" and can we improve on this? Should conscious body-mind-emotion awareness be considered a practical part of the vocal pedagogue's formation and training? 


\section{Funding}

None. This research did not receive any specific grants from funding agencies in the public, commercial, or non-profit sectors.

\section{Disclaimer}

The content of this article is the sole responsibility of the author and does not represent an official opinion of their institutions or the Revista de Investigación e Innovación en Ciencias de la Salud.
The above is just a few of the questions that have been raising singers and vocal teachers heads over the past few years, as I have dedicated a large amount of my Alexander Technique teaching practice to working with them.

And most curiously, many of these questions have been coming directly from the singers themselves, in a desire to understand and integrate their whole self in their singing and not just focusing all of their attention on the production of sound through mechanics and technique alone, which now is believed to be more isolating and separating than inclusive and integrating. The same singers have indicated a deep desire (need) to express and communicate from a place and a space of integration, freedom, ease, wholeness and truth, none of which requires them to misuse or abandon themselves or their vocal technique.

\section{Reflection}

\section{So what is the Alexander Technique (AT)?}

Frederick Mathias Alexander (1869-1955), an Australian actor, made some groundbreaking discoveries over 110 years ago in his homeland, where he found himself suffering from severe vocal and breathing problems, which left him without a voice to perform (he was a trained and working Shakespearean orator at the time). This led him to a deeply developed new awareness and ultimately a healthier use of his whole self. Some of his discoveries included the unconscious habitual movements and unnecessary tensions and actions that can induce detrimental tension in the voice (and overall), as it is referenced in his book, Man's Supreme Inheritance (1910) [1].

The AT is a way to re-educate the habitual way of reacting to the demands of the movements and activities of daily life, in order to build a more conscious way of using one's own body; it is a global method of understanding that the human being is an integrated being (body \& mind) and not separate parts, since one affects the other either directly or indirectly.

And for singers, among the many benefits of the AT is helping them sing without (unnecessary) tension. It is based on principles that help to establish a reliable coordination in the musical task, since it improves the way in which we coordinate ourselves in our daily use of our psycho-physical structure. It begins with identifying our unhelpful/unhealthy habits of use and then inhibiting those patterns of behaviour, thus giving us the power and freedom to choose consciously how we wish to respond. In doing so, we pay attention to ourselves, our surroundings, and connect more to the present moment while noticing, expanding, and ultimately playing within that space between stimulus and response. This gives us the possibility to make new conscious choices and re-educate or retrain or neuromuscular-emotional responses to internal and external stimuli. All of which are, in my humble opinion, immeasurable skills for both the performing artist and vocal pedagogy.

Alexander Technique has been an intricate part of the curriculum for decades at many arts educational institutions across the US, Canada, Australia, and Europe. It is considered a much needed part of the programme at Juilliard School of Music, Manhattan School of Music NYC, LAMDA, RADA, Royal College of Music London, LA Opera Young Artist Program, Metropolitan Opera's Lindemann Young Artist Development Program NYC, Sydney Opera House, Royal Opera House Young Artist Program London and, since January of 2014, at The Opera Studio of Bellas Artes 
in Mexico City, where I am the resident teacher. The student's whole process and development as a singer and artist are at the heart of the work and its supporting role in all of the other classes and training.

The following are some definition and quotes about the Alexander Technique by Frederick Mathias Alexander:

- "Our thoughts translate into physical tensions" [2], taken from the book Constructive Conscious Control of the Individual (1923).

- "The quality of our movements are directly proportionate to the quality of our thinking" [3], taken from the book The Use of the Self (1932).

- "If we stop doing the wrong thing, the right thing does itself" [4], taken from the book The Universal Constant in Living (1941).

I believe that some of these tensions can be so unnecessary and become quite harmful depending on where our conscious thinking is at. These tensions can often fly under our radar, as we become accustomed to excess force and tension in order to create sound. However, how we are sending these directions (thoughts behind actions) and coordinating them can be remedied by learning and applying the AT, so as to undo and reestablish balance and freedom in a most natural and free way.

I also suggest that in the context of a singer or a vocal pedagogue, the previous quotes by Alexander can be interpreted in the teaching of singing as "get out of your own way", in order to stop interfering with your natural design. This brings me to the next question that has been coming up and is being addressed more and more in vocal pedagogy, but it is still lacking from what I can see... and that is vocal and general anatomy of the vocal and the entire physical instrument.

\section{Can a more consciously informed body better inform the voice?}

As a singer myself, I went through a period of losing my voice, suffering hoarseness and intense discomfort, and I really did not know why at the time. This discomfort was also accompanied by severe lower back pain, lethargy, which ultimately contributed to continued low self-esteem and moments of great anxiety at the thought of losing my voice completely and not being able to sing.

I was twenty two at the time, touring with a musical group and moving from city to city every three to four days. The schedule was challenging and I was a long way from really knowing and/or understanding what my use had to do with my vocal health.

I now understand that part of the problem was that my formal voice studies hardly ever mentioned the importance of body-mind balance and coordinated use of the whole body instrument when singing. There was hardly any mention of mapping things out or understanding the working natural vocal and body anatomy in the production of sound. My classes consisted of just focusing on vocal technique, and producing an acceptable and sometimes impressive vocal sound with, what later revealed itself to be, incredibly excessive amounts of body and vocal apparatus tension, from a person and an instrument that was out of balance and alignment, and who, as a result of all this, did not really connect or understand what in fact was taking place and her role in this. 
Understanding that she was a whole unique person with her own body, voice, and sound. And in my case, as with so many others, knowledge would have been power. So as soon as I realized that my problems were not isolated and that they did not get fixed by doing more, the solution was found in discovering that there was in fact so much I needed to undo, relearn, and rebalance. This ultimately leads to a more integrated self while singing, thus, building conscious awareness and managing my singing with constructive conscious control of the use of myself, which bled into the rest of my life in all manners, especially in my creative art and teaching.

\section{So, what is a vocal pedagogue's role when it comes to the singer's mind-body education and experience?}

It seems to me that singers today want more from their music and vocal expression than just accolades, fame, and applause. I mean they will not say no to a standing ovation and a nice paycheck, but what I mean here is that this seems to not be what they want as their only goal. Many singers have voiced the belief that the beauty of the creative arts is that we get to connect, communicate, and express ourselves! I believe the students of today also express a human desire to communicate, to be heard and to express and share emotions, thought, and sentiment through their song and music.

I sometimes wonder if the art (and teaching) of singing may still today focus just that bit too much on the production of something so technical, mechanical, and in some cases bordering on unnatural, that, as a result, we may in fact have moved farther away from our natural and intuitive free vocal sound.

And by natural and intuitive I refer to things like our primordial sound referenced in the work of Janice L. Chapman, in her book Singing and the Teaching of Singing, A Holistic Approach to Classical Voice [5]. Lest we forget that the singing voice has been practiced since prehistoric times, long before spoken language came into existence, as a mode of communication. The evolution of the singer today, whether classical, lyrical, contemporary or pop, seems to me to be in a moment of reckoning and redefinition.

I am aware that there are also several new schools of thought and pedagogies that are popping up in the last few decades that address and take into consideration these realities and the need for singers to come back to a holistic and integrated way of vocal expression, among them, many well respected authors, experts, doctors, and pedagogues, such as Janice Chapman [5], Ted Dimon [6,7,8,9], Jane Ruby Heirich [10], Barbara Conable [11], Kristin Linklater [12], Pedro de Alcantara [13], Claudia Friendlander [14], Patsy Rodenburg [15], Rafael García [16], and Carolyn Nicholls [17], all of whom consider the body and the voice as one integrated entity. And the majority of whom incorporate this into their philosophies, research, findings, and pedagogies, including mention and application of the work and principles of the Alexander Technique.

\section{As teachers, is what we believe to be good singing posture really "good"?}

I recently google searched "good singing posture" and quite surprisingly was directed to the top hit website which contained an excerpt from a book called [18] How to train singers by Larra Browning-Henderson, written in 1979 (click HERE to read it). Alarmingly, I was then reading a set of indications to attain "correct" singing posture, which included some rather outdated and rather anatomically harmful instructions, such as: 
shoulders should be held back and down with chest held high, abdomen should be flat and firm, the shoulders are straight and the chest is wide to allow proper breath support and control. These positions may not become a habit immediately, but with practice should. There are also exercises available to aid in correct body alignment e.g. stand up against a wall, placing heels, calves, buttocks, shoulders, and head touching the wall [19].

Practically all of what was recommended in the previous quote goes against our natural design and thus our freedom of sound. Therefore, it is interesting to me that this misinformation is out there and available for anyone who googles "correct singing posture". Of course, I can see the well-wishing intentions behind this advice for singers, but let me be clear, I believe there are way too many trigger words for singers that can be so easily misunderstood and lead to unnecessary holding, and tensing, doing quite the opposite to freeing the singing voice and instead tensing it.

The doing of posture is one example! Nature (and the AT) purports that posture is not something we do, it is a part of our natural design; therefore, we must allow our body's own natural balance to establish itself, for the task at hand. That way, we let go of anything that is interfering with our natural poise and balance and preventing us from being free to move, sing, speak, walk, talk, run, play, etc.

How many people today, when they have the slightest doubt or query, immediately google it? Therefore, it is alarming to me, that upon doing this, one is directed to a book written in 1979 no doubt with good intentions - , containing rather unreliable science or fact based on what we know and understand today. Consequently, I strongly believe that we must educate our students and equip them with a desire to understand their body instrument's natural design.

I also highly recommend that both singers and musicians study body-mapping, a method originated by AT teachers Barbra Conable and William Conable [11], through which one learns to gain access to one's own body map through self-observation and self-inquiry. The student corrects his or her own body map by assimilating accurate information provided by kinesthetic experience, the use of a mirror, anatomical models, books, pictures, and teachers. Can this be integrated into formal artistic educational programs? Maybe even for both students and faculty? Another wonderful reference for body mapping is the book What every singer needs to know about the body [19].

\section{Should conscious body-mind awareness be considered a practical part of the vocal pedagogue's study and training?}

I invite you to take a moment to observe and sense what reading those words may have awoken in you? Did it motivate, inspire or open your curiosity? Or did it create any panic and/or discomfort, being somewhat far from the traditions of how you were taught singing and vocal pedagogy and how you may indeed be teaching voice today? Would you be up to explore something that could ultimately aid and integrate both yours and your vocal student's experience?

Can we observe in our students today a youthful curiosity and passion and excitement with which we can transform a moment of great learning? The Greeks refer to it as kairos, which I read in the book The Art of Is by Steve Nachmanovitch [20].

Are we open to this? Are we willing to maybe evolve and update our ideas, bringing them into the here and now, even letting go of jaded and expired ideologies? Gratefully taking with us what is still relevant and helpful today and letting go of what is no longer helpful or has 
been deemed to be less than reliable or somewhat misinformed, given that we now have a lot more science and research that tells us how things really are?

Does our approach to breathing in vocal pedagogy need to be updated? Could we benefit from a possible refresh in order to include more about the breathing's natural function and mechanism so as to provide more space for integration and direction, in order to arrive at a more natural and free sound and less of a mechanical or superficial one? Rather than the doing of breathing, but the permitting, directing and allowing of it through a greater understanding of the mechanics involved, body mapping, full body breathing, etc. could this quite possibly contribute to a generation of much more informed and integrated singers rather than mechanical sound makers?

For example, let's think of breathing and remember that its very nature began with an exhalation and the subsequent inhalation came in of its own natural accord based on our body's natural design! Where vocal expression is concerned, can the inhalation be connected and inspired by what it is we wish to communicate on that breath? (just like in speech). Thus, contributing to a more connected, integrated, naturally authentic, freer, and easy vocal sound. More believable and more pleasant perhaps on all levels, be them sound, frequency, energy or emotion?

As one of my Alexander Technique mentors, Theodore Dimon, wrote in a recent blog from his website:

If we want to breathe well, we do not need to do anything to get air into the body, but simply to secure the coordinated, reflexive working of the system on which the movements of breathing depend.

This is where our habitual tensions come into play. When we interfere with our natural support by tightening the neck muscles, pulling back the head, raising the chest, and narrowing the back, then the ribs will not fully expand and contract. The breathing will operate to our best advantage when we are properly coordinated in an overall sense [21] (https://www.dimoninstitute.org/).

Here in Latin America I have witnessed so far that albeit among the lesser known techniques or approaches, one of the more effective long-term solutions to mind-body unity and coordination is the Alexander Technique. A conscious re-educational, preventive, and integrative tool for vocal pedagogy. A psycho-physical-emotional vocal practice if you will. And the more people know about it, learn and apply it, the more the interest and curiosity grows.

\section{Conclusion}

I believe that where our direction goes, our energy goes, and if there is excess tension present, it is more often than not directly connected to confusion and misdirection.

I feel like we are sometimes trapped in a culture of just fix it, do this, etc. which focuses on isolating the problems (aka symptoms) and not digging a little deeper to see what might be the underlying cause of the discomfort or pain. Thus, we may manage to fix something in the short term, but the problems more often than not persist, provoking, most of the time, the detriment of our vocal health and freedom.

I believe that we can all admit that the needs and demands of the singing world are vast and can be rather overwhelming for young singers these days, with so much emphasis being placed on being the best and standing out, so my questions to you, dear reader, are: 
- Is this acquisition of fame as quickly as possible and at all costs, with a no win no gain approach, really serving our community?

- Why don't we incorporate and include more body-mind (Psychophysical) education into vocal pedagogy?

- Would you as a vocal pedagogue, singer or vocal educator consider aligning and/or joining forces with an Alexander Technique practitioner or other body work professional in order to best serve the needs of our singers and nurture the nature of this beautiful art form?

- And finally, could this knowledge and its application and practice develop more integrated, conscious healthier, and happier singers? I for one believe this to be true!

\section{References}

1. Alexander FM. Man’s Supreme Inheritance. Sixth Edition. London: Mouritz; 1996.

2. Alexander FM. Constructive Conscious Control of the Individual. York: Methuen \& Co. Ltd; 1923.

3. Alexander FM. The Use of the Self. York: Methuen \& Co. Ltd; 1932.

4. Alexander FM. The Universal Constant in Living. 4th Edition. London: Mouritz; 2000.

5. Chapman JL. Singing and Teaching Singing: A Holistic Approach to Classical Voice. San Diego: Plural Publishing Inc.; 2004.

6. Dimon TJr. Your Body, Your Voice. Berkley: North Atlantic Books; 2011.

7. Dimon TJr. Anatomy of the Voice. Berkley: North Atlantic Books; 2017.

8. Dimon TJr. The body in Motion, Its Evolution \& Design. Berkeley: North Atlantic Books; 2011.

9. Dimon TJr. The Undivided Self, Alexander Technique and the control of stress. London: Souvenir Press Ltd; 1999.

10. Heirich J. Voice \& the Alexander Technique (Active explorations for speaking \& singing). Berkeley: Mornum Time Press; 2005.

11. Conable B. What every musician needs to know about their body. Portland: Andover Press; 1998.

12. Linklater K. Freeing the Natural Voice. Hollywood: Drama Publishers. Quite Specific Media Group Ltd; 2006.

13. Alcantara de P. Indirect Procedures. A musician's guide to the Alexander Technique. Oxford: Oxford University Press; 1997.

14. Friedlander C. Complete Vocal Fitness: A Singer's Guide to Physical Training, Anatomy, and Biomechanics. Maryland: Rowman \& Littlefield Publishing Group, Inc.; 2018.

15. Rodenburg P. Second Circle. London: W. W. Norton \& Company U.K.; 2008.

16. García Martínez R. El Entrenamiento Mental para Músicos. Barcelona: Red Book Ediciones; 2017. 
Vocal Pedagogy and the Alexander Technique

17. Nicholls C. Body, Breath \& Being. Hove: D \& B Publishing; 2008.

18. Browning-Henderson L. How to train singers. New York: Parker Publishing Company Inc.; 1979.

19. Malde M, Allen MJ, Zeller K. What every singer needs to know about their body. San Diego: Plural Publishing; 2017.

20. Nachmanovitch S. The Art of Is. Novato: New World Library; 2019.

21. Dimon TJr. Dimon Institute [Internet]. 2020 [Cited Nov 26]. Available from: https:// www.dimoninstitute.org 